\title{
LGBTQ Studies and Interdisciplinarity: A Citation Analysis of Master's Theses
}

\section{Vince Graziano}

abstract: Emergent programs or newly established areas of study are often viewed as interdisciplinary. But how is interdisciplinarity defined or measured? The identification of research methods and the selection of objects of inquiry are significant elements in this definition. Citation analysis, however, also plays a role. Citation patterns in master's theses written at Concordia University in the field of LGBTQ studies at Concordia University in Montreal, Canada, indicate, at first glance, that the field is highly interdisciplinary. The field cites from different disciplines or areas of study as defined by the Library of Congress Classification (LCC) system. A closer examination reveals that 43.3 percent of all classified citations are about LGBTQ topics, leading to the conclusion that LGBTQ studies shows an average, rather than a high, level of interdisciplinarity, and that the field has a distinct disciplinary focus. This finding informs reference work, research assistance, and bibliographic instruction.

\section{Introduction}

The history and development of lesbian, gay, bisexual, transgender, and queer (LGBTQ) studies are recent. Academic pursuits in gay and lesbian studies began in the 1970s in some colleges and universities in the United States and Canada. The City College of San Francisco (CCSF) created a gay literature course in 1972 and formed a Department of Gay and Lesbian Studies in 1988. The department changed its name to Gay, Lesbian and Bisexual Studies in 1996 and is now called LGBTQQI Studies, an abbreviation that stands for lesbian, gay, bisexual, transgender, queer, questioning, and intersex. ${ }^{1}$ At the City University of New York (CUNY), the newly founded Gay Academic Union held its first conference in November 1973, with 200 attendees, and started a gay and lesbian studies program in 1986, now called LGBTQ studies, and created the Center for Lesbian and Gay Studies in 1991, now the Center for LGBTQ Studies. ${ }^{2}$ In Canada in the mid-1970s, the University of Toronto School of Continuing Studies offered a course titled The Gay Experience: A Sociological Perspective taught by a sociology professor. ${ }^{3}$ The university introduced the a Sexual Diversity Studies program in 1998 and launched the a related graduate program in 2008. In 2001, Yale University endowed a chair in LGBT studies, after having failed in 1997, and Harvard University endowed a similar professorship in $2009 .{ }^{4}$ By 2015, about 40 colleges and universities in the United States offered minors in LGBTQ studies, LGBTQ programs or courses were featured in 13 universities in Canada. ${ }^{5}$ 
The Journal of Homosexuality, in a special issue published in 1993, declared that gay and lesbian studies had emerged by the early 1990s. ${ }^{6}$ The underlying assumption in this emergence is that gay and lesbian studies, or LGBTQ studies, had become a field of study or discipline. For Karen Antell, the "emergence" of LGBTQ studies "creates the interesting challenge of providing library support to an interdisciplinary field without a long-standing body of scholarly literature." She claims that LGBTQ studies has a "very high rate of cross-disciplinary citations."7 There are two assumptions in these statements: the lack of a long-standing body of scholarly literature and high interdisciplinarity. Many new and emerging fields are considered interdisciplinary, and many established disciplines exhibit some level of interdisciplinarity. With its recent emergence, LGBTQ studies would normally show a high level of interdisciplinarity, but this hypothesis has not been tested empirically.

This study's primary goal is to measure and assess the interdisciplinarity of LGBTQ studies through an examination of 28 master's theses, with 3,243 citations, written between 1991 and 2013 at Concordia University in Montreal, Quebec, Canada. What do citation patterns reveal about the field? Is LGBTQ studies based on its own scholarly literature, and if so, to what degree? Or is it grounded in the scholarly literature of other disciplines, particularly since the early 1990s? In other words, do citation patterns indicate a disciplinary focus, are scattered over a large number of disciplines, or are they concentrated in a few fields of study? With at least 20 years since the emergence of LGBTQ studies, does the field now have a substantial body of literature? Are there any differences in this body of literature by document type, namely monographs, chapters in books, journal articles, and popular periodicals? Does each format display a disciplinary focus, or does interdisciplinarity vary by document type? What are the leading books, authors, journals, and popular periodicals? Does each of these display a concentration on LGBTQ studies, or are they borrowed from other disciplines? In other words, does LGBTQ studies resemble a traditional discipline with its own literature, or is it based on the literatures of other fields? The answers to these questions may inform library practice, specifically reference work, research assistance, and library instruction.

\section{Setting}

Concordia University is a large, comprehensive urban university, with more than 45,000 students. In 1977, the province of Quebec became the first jurisdiction in North America to prohibit discrimination on the basis of sexual orientation, and Montreal is generally regarded as 
an open and tolerant city. Within this context, Concordia is uniquely positioned as a safe and welcoming campus, with a climate that is accepting and respectful for LGBTQ students, faculty, and staff. The student group Queer Concordia, which is financed by a $\$ 0.02$ per credit fee levy approved by undergraduate students, is highly inclusive and brands itself as the "campus resource centre for queer, lesbian, gay, trans*, two-spirited, bisexual, asexual, intersex, questioning, and allies." " A collective agreement between the faculty association and the university prohibits discrimination and harassment on the grounds of sexual orientation. Concordia is a safe space to study, work, teach, and conduct research on LGBTQ topics.

The growth of LGBTQ and sexuality studies at Concordia further attests to this respectful climate. The university began developing its curriculum in gay and lesbian studies insince the mid-1980s. The first lesbian studies course was created in 1985 at the Simone de Beauvoir Institute, which houses the Women's Studies Department. The first gay studies course on literature and film was introduced in 1989. In 1992, Concordia and the Université du Québec à Montréal cohosted La Ville en rose (The City in Pink), Quebec's first Lesbian and Gay Studies Conference. In 1993, Concordia introduced the Community Lecture Series on HIV/AIDS, and the following year the university inaugurated the course HIV/AIDS: Cultural, Social and Scientific Aspects of the Pandemic. The course is part of an undergraduate minor in interdisciplinary studies in sexuality, which began in September 1998 and is offered jointly by the Faculty of Arts and Science and the Faculty of Fine Arts. The purpose of the minor is to investigate empirical, theoretical, and creative aspects of sexuality, with its roots in the "sexual revolution" of the $1960 \mathrm{~s}$, the feminist movement, and gay and lesbian liberation. ${ }^{9}$

In 2014, the Concordia University Senate approved a major in interdisciplinary studies in sexuality, which awaits implementation. Although there is no graduate program in LGBTQ studies at Concordia and there are no plans to create one, there is ample student interest and faculty expertise in LGBTQ and sexuality studies. Students have written master's theses on LGBTQ topics in several departments, including Art History, Communication Studies, Creative Arts Therapies, Education, English, Film Studies, Geography, Political Science, Sociology and Anthropology, and Theological Studies. One of the 28 theses was written within the university's Individualized Program, a graduate program that emphasizes interdisciplinary scholarship (see Table 1). 


\section{Table 1.}

\section{Theses by department}

\begin{tabular}{lr} 
Department & $\begin{array}{r}\text { Numb } \\
\text { theses }\end{array}$ \\
\hline Communication Studies & 9 \\
Sociology and Anthropology & 7 \\
Art History & 2 \\
Creative Arts Therapies & 2 \\
English & 2 \\
Education & 1 \\
Film Studies & 1 \\
Geography & 1 \\
Political Science & 1 \\
Individualized Program & 1 \\
Theological Studies & 1 \\
Total & $\mathbf{2 8}$
\end{tabular}

Total 28

\section{Literature Review}

There are several definitions of interdisciplinarity. The Oxford English Dictionary defines it as "pertaining to two or more disciplines or branches of learning," while multidisciplinary is described as "combining or involving several separate disciplines." ${ }^{10}$ Reflecting this definition, Jean-Pierre Hérubel explains that interdisciplinarity includes two or more disciplines that are actively engaged, "synthesizing their efforts within a given range of objectives and conditions," whereas multidisciplinarity involves several disciplines without integration among them. ${ }^{11}$ It is unclear how this description can be applied to citation analysis. In a 1991 editorial, Michael Winter separates interdisciplinarity into two criteria: integrative and territorial. ${ }^{12}$ This classification is more easily applied to citation analysis, wherein citations outside of the field are determined to be integrative and citations from within the field are territorial. Like many disciplines, LGBTQ studies exhibits both the integrative and the territorial. The question is, to what extent does LGBTQ studies cite within and outside its own field? Previous studies provide points of comparison.

All disciplines or areas of study display some level of interdisciplinarity. Jonathan Levitt, Mike Thelwell, and Charles Oppenheim hypothesized that social science disciplines 
became more interdisciplinary from 1980 to 2000. They measured the interdisciplinarity of 14 disciplines by the subjects of the journals assigned by Web of Science, a scientific citation indexing service. They found that the median percentages of citations to their own fields was 44.1 percent in 1980, 49.1 percent in 1990, and 43.4 percent in 2000. For specific disciplines, citations to their own fields in 2000 ranged from a low of 18.5 percent for psychology to a high of 56.9 percent for economics, with sociology at 33.1 percent, education at 49.3 percent, business at 41.3 percent, and political science at 44.9 percent. ${ }^{13}$ Less than 50 percent of references were of the territorial variety for traditional social science disciplines such as education, sociology, psychology, political science, and business.

The article by Levitt, Thelwell, and Oppenheim demonstrated one method of measuring interdisciplinarity, while several other studies used the Library of Congress Classification (LCC) system. In a study of master's theses in history, Graham Sherriff found that 49.6 percent of citations were classified in history, represented by the LCC classes C, D, E, and F, leading him to conclude that "historical research does not have a high degree of interdisciplinarity." 14 Virginia Kay Williams and Christine Lea Fletcher examined 250 master's theses in engineering, a discipline not usually viewed as interdisciplinary. One of the objectives of their study was to gauge the extent to which engineering students cite journals from non-engineering disciplines. They found that 44 percent of titles were classed in technology, as per the LCC system, and that the majority of cited journals were from non-engineering disciplines. ${ }^{15}$ In a study of 180 master's theses in psychology, Bluma Peritz and Dina Sor found that 52.6 percent of the citations were to psychology, which was ascertained from the title of the work cited or the journal in which the citation appeared. They concluded that psychology students need to have access to library resources in other disciplines. ${ }^{16}$

In the field of tourism studies, Juris Dilevko and Keren Dali selected 80 articles, with 3,482 citations, from two tourism scholarly journals, finding that 45.3 percent of citations were classified in the LCC class G149-G550 for travel and tourism, and a further 5.9 percent were in recreation and leisure, represented by the LCC class GV. The total was 51.2 percent, which led to the statement that "tourism studies is a tremendously rich interdisciplinary field." ${ }^{17} \mathrm{Li}$ Zhang's study of agricultural economics, described as a hybrid field that began in the first decade of the twentieth century, found that 57.1 percent of citations were classified in LCC classes HB for economics and or $\mathrm{S}$ for agriculture. Although the author states that the field shows "strong 
interdisciplinary components," she does not provide points of comparison with other studies. ${ }^{18}$ Based on these findings the interdisciplinarity of agricultural economics and tourism studies is lower than other fields. In a 1971 study, Robert Broadus reported data for the fields of sociology, classified in the LCC classes HM to HX, and education, defined by the LCC class L. Citation analyses in sociology showed that 16.8 percent to 42.8 percent of citations were to sociology, while citations in education to its own subject ranged from 56.3 percent to 67.9 percent. ${ }^{19}$ Though dated, this study illustrated that sociology was more interdisciplinary and that education less so, at least in the 1950s and 1960s.

Some fields exhibit a higher interdisciplinarity with lower percentages of citations to their own fields. Joy Thomas examined journal citations in master's theses in social work, a field that she considered interdisciplinary, and found that only 23.7 percent of journal citations came from social work journals. ${ }^{20}$ Stating that social gerontology "clearly fits the paradigm of an interdisciplinary field," Elaine Lasda Bergman found that 23.7 percent of the journal articles cited were in the social gerontology field, concluding that "there is a small, definitive core of materials specific to gerontological research." 21 Literature use by scholars in anthropology, as reported by William Robinson and Paul Posten, showed that 27 percent of journal citations were classified in anthropology using the LCC class GN. ${ }^{22}$ As described by Thomas Weissinger in 2010, citations in two core black studies journals cited other black studies journals at a rate of 23 percent, demonstrating that the field has a high level of interdisciplinarity. ${ }^{23}$

Three studies showed fields that were less interdisciplinary. In another article by Li Zhang, this one about international relations, 37.8 percent of the citations were to international relations and the related fields of political science and public administration, as defined by several LCC classes from JA to JZ. Zhang concluded that the 62 percent of citations derived from other disciplines "reflects a high-level interdisciplinarity." 24 Joy Thomas used the journals paid for by psychology's portion of the library budget to measure the percentage of journals cited by graduate students in 342 psychology theses. She found that 37.4 percent of journal citations came from psychology journals. ${ }^{25}$ Molly Strothmann, in her study of non-social work journals in social work research, reported that 35.5 percent of 19,948 citations referred to social work journals. $^{26}$

There is a discrepancy between the percentages observed by Thomas and Strothmann for social work, with Thomas reporting 23.7 percent and Strothmann finding that 35.5 percent of 
citations were to social work journals. Among the possible explanations are the dates of the studies. Strothmann's article appeared in 2010, 17 years after Thomas's study. The different methods of measuring interdisciplinarity may also explain the discrepancy. Thomas used the social work fund of the library budget, while Strothmann utilized the Library of Congress Classification system. The 12 percent difference seems significant, but compared to other studies, both percentages are low, showing that social work has a relatively higher level of interdisciplinarity.

Different methods of measuring interdisciplinarity may preclude meaningful comparisons. Seven of the 13 studies just outlined, however, used the Library of Congress Classification system as the method of measurement. One study used the subjects assigned to journals by Web of Science, another employed the titles of the works cited, two used the subject's portion of the library budget, and some did not report a method. Different methods appear to produce different results, but the highest percentage of citations within the field of study is 57.1 percent, excluding Broadus's dated 1971 study. The extent to which a field cites within its own discipline ranges from a low of 23 percent to a high of 57.1 percent. With the method of measurement notwithstanding, and Broadus's study eliminated, the median of all the percentages is 37.6 percent, and the median of the six studies that used LCC is 40.9 percent. It is clear that All the fields or disciplines are interdisciplinary, but the level of interdisciplinarity varies. Disciplines with percentages in the 20s and 30s exhibit higher interdisciplinarity, while those in the 40s and 50s present a relatively lower interdisciplinarity.

There has been one citation analysis of the scholarly literature of LGBTQ studies. Karen Antell sampled 131 articles, with 4,321 citations, from the LGBT Life database. One of the questions she wanted to answer is whether the scholarly literature of LGBT studies cited "mainly other scholarly literature in the same field," or if it "draws heavily" on literature from other disciplines. Antell based her study on primary subject headings for periodicals in Ulrichsweb, the online version of Ulrich's Periodicals Directory, and those for books in WorldCat, a catalog maintained by the subscribing member libraries of the Online Computer Library Center (OCLC). She assigned five broad discipline categories - social sciences, humanities, science/technology, medicine, and law - to the 3,651 citations to scholarly journals, academic and popular books, and conference papers. She found that the social sciences accounted for 63 percent of the citations, 
medicine for 24.5 percent, humanities for 7.1 percent, science/technology for 3.2 percent, and law for 2.3 percent. $^{27}$

The 63 percent of citations accorded to the social sciences is higher than any of the percentages reported in the thirteen 13 studies noted aboveearlier, some of which Antell mentions in her article. It is possible that LGBTQ studies is may be highly interdisciplinary, particularly if the social sciences awere divided into their component disciplines, but Antell does not measure the interdisciplinarity of LGBTQ studies itself, preferring instead to count the citations to the social sciences as the "same field." In this respect, her methodology is questionable because she wanted to know whether LGBTQ studies cited sources from within the "same field." Her evidence regarding the interdisciplinarity of LGBTQ studies is incomplete and unconvincing, precluding an appropriate answer to her question. Her study cannot be used as a point of comparison.

\section{Methodology}

The first step was to select an appropriate number of theses to create a decent sample size of citations. Most theses at Concordia are classified in LE in the local catalog. Since subject headings are not assigned to theses, it was necessary to use keyword searches in the catalog and the institutional repository, both of which include abstracts, to identify theses written on LGBTQ topics. The keywords were gay, gays, lesbian*, homosex*, queer*, bisexual*, transgender*, transsexual*, intersex*, and $l g b t^{*}$. Only those theses that featured LGBTQ topics prominently in their titles and abstracts were selected. Doctoral dissertations were eliminated as because they were few in number. Theses written in French were removed from the list because they have different references from their English language counterparts. Theses about HIV/AIDS were chosen if they featured LGBTQ communities. Literary works submitted for a master's degree in English (Creative Writing) were also excluded, because they do not have bibliographies. This study included all of the remaining 28 theses that matched these criteria.

Each of the 3,243 citations was recorded manually and entered into Excel spreadsheets, with one horizontal line per citation. For each citation, the following was recorded into vertical columns: title (book, serial, or document), author, format, publication year, age, language, ownership, Library of Congress Classification, and discipline or area of study based on LCC. The formats with the most citations were monographs, scholarly journal articles, chapters in edited books, general newspapers, websites, conferences, and popular periodicals, defined as 
general interest magazines and community periodicals. If some of the information was unknown, unverifiable, or not applicable, the field in the Excel spreadsheets was left blank. For example, the publication year, call number, discipline, and age for undated websites were left blank. Each citation was verified in the library catalog to obtain a call number. If the item was not found, then WorldCat was used for monographs and Ulrichsweb for serials. If a source could not be verified or if a format was not normally catalogued (such as websites and interviews), the LCC call number and discipline columns were left blank. There were 324 citations not assigned a call number or a discipline. Ownership was defined as physical holdings as well as access to licensed material. Age was calculated as the date of submission less the publication year of the citation.

The Library of Congress Classification system was used to measure interdisciplinarity. LCC assigns a single subject category, whereas Library of Congress Subject Headings (LCSH) and those subjects used in Web of Science, for example, offer multiple subject categories, which can make it difficult to assign a single discipline to a citation. Ben Christensen identifies a problem with the classification of multi-topical works. He cites the example of the subject heading "Gays_-Violence against" that is classified in HV6250.4, which "refers to homosexuals as a class of victims of crimes." Moreover, he lists 16 of the 21 classes in LCC in which works about LGBTQ topics can appear. ${ }^{28}$ Emily Drabinski states that LCC and LCSH "fail to accurately and respectfully organize library materials about social groups and identities that lack social and political power." She mentions "activist catalogers" who exert pressure on the Library of Congress to catalog materials correctly and without bias. She gives the example of a 1967 edition of a book about transsexuality that was classified in RC560, with books on masturbation and sex addiction, which suggests that transsexuality is a psychological disorder. The 2000 edition of the same book is classified in HQ77.8, the category labeled as transsexualism. ${ }^{29}$ Drabinski claims that both call numbers are biased. Clearly, changes have been made, but perhaps more changes are necessary.

The methodology using the Library of Congress Classification system to measure interdisciplinarity is both clear and problematic. It is clear because LCC provides a conventional measurement, with LGBTQ studies represented by the call number range HQ74-HQ77.95. This method is also problematic because LGBTQ topics in the LCC system are spread out over several classes. The Journal of Gay \& Lesbian Issues in Education, for example, is classified in 
education, and the book Epistemology of the Closet by Eve Kosofsky Sedgwick, a seminal work in LGBTQ studies, is categorized as literature.

Many resources classified in literature, sociology, film studies, and other fields deal with LGBTQ topics, bearing in mind Christensen's point that 16 LCC classes can be used for LGBTQ topics. An extra column was added to the Excel spreadsheets. Each citation that was not classified in LGBTQ studies was assigned a topic of LGBTQ studies in this column if it obviously fit within the category. "Obvious" was defined by the words homosexuality, gay, lesbian, bisexual, transgender, queer, intersex, same-sex, sexual orientation, homophobia, homoeroticism, and closet. One of these words or terms needed to appear in the titles of articles, book chapters, and monographs. The books Tendencies by Eve Kosofsky Sedgwick; the History of Sexuality by Michel Foucault; Sexual Behavior in the Human Male by Alfred Kinsey, Wardell Pomeroy, and Clyde Martin; and Gender Trouble: Feminism and the Subversion of Identity by Judith Butler were also assigned a topic of LGBTQ studies because they were known LGBTQ books.

There are two types of LGBTQ citations: those classified in HQ74 to HQ77.95 (henceforth, classified is used to describe this type of citation); and those that were assigned an LGBTQ topic based on the titles of the works (henceforth, topic is used to designate this type of citation). The latter included articles in journals, newspapers, and popular periodicals, as well as chapters in edited collections. Some monograph citations were classified outside of HQ74 to HQ77.95 but were really about LGBTQ topics. Unclassified materials such as websites and personal interviews were not assigned a topic of LGBTQ studies, though many of the 122 websites dealt with LGBTQ topics. This methodology, while slightly unorthodox, is nevertheless sensible because LGBTQ studies, like African American studies, women's studies, and Latino/a studies, are about social groups. The Library of Congress Classification system permits the categorization of social groups within several classes, as is the case with LGBTQ studies. In this sense, LGBTQ topics are co-disciplinary; they are about two disciplines, the discipline in which they are classified and the LGBTQ topic based on their titles. For example, a psychology journal features psychology articles. The same psychology journal can include articles on LGBTQ topics, making the citation co-disciplinary, about both psychology and LGBTQ studies. Counting both types of citations is necessary to determine the level of interdisciplinarity of LGBTQ studies. 


\section{Results}

Before measuring and assessing the interdisciplinarity of LGBTQ studies through the lens of master's theses, it is necessary to identify the disciplines from which LGBTQ studies borrow. Table 2 shows the number of citations by discipline or category, along with the percentage of total classified citations. The discipline with the highest number of citations was LGBTQ studies, followed by literature, sexuality studies, and sociology. Those items classified in medicine were subdivided into three areas: HIV/AIDS, psychiatry, and art therapy. Together, the field of medicine accounted for 9.5 percent of classified sources. Antell reported that 24.5 percent of references to scholarly journals, academic and popular books, and conference papers were in the field of medicine. Limiting this study's medical references to the same document types specified by Antell produced a percentage of 11.3 percent, significantly lower than the 24.5 percent.

Despite the lower percentage, medicine still accounts for the second most cited discipline in this study.

Table 2.

Citations by discipline

\begin{tabular}{llccc}
\hline $\begin{array}{l}\text { Library of Congress (LC) call } \\
\text { number }\end{array}$ & Discipline or category & $\begin{array}{c}\text { Number } \\
\text { of } \\
\text { citations }\end{array}$ & $\begin{array}{c}\text { Percentage } \\
\text { of total } \\
\text { classified } \\
\text { citations } \\
(\mathbf{N = 2 , 9 1 9 )}\end{array}$ & $\begin{array}{c}\text { Cumulative } \\
\text { percentage of } \\
\text { total } \\
\text { classified } \\
\text { citations }\end{array}$ \\
\hline HQ 74-77.95 & LGBTQ studies & 633 & $21.7 \%$ & $21.7 \%$ \\
PQ, PR, PS & Literature & 252 & $8.6 \%$ & $30.3 \%$ \\
HQ 12-449, HQ1075- & Sexuality studies (non- & 245 & $8.4 \%$ & $38.7 \%$ \\
\multicolumn{1}{|c|}{ 1075.5 } & LGBTQ) & 210 & $7.2 \%$ & $45.9 \%$ \\
HM, some HQ,HT,HV & Sociology & 199 & $6.8 \%$ & $52.7 \%$ \\
A & General works & 166 & $5.7 \%$ & $58.4 \%$ \\
RA643-645, RC607 & Visual arts & 124 & $4.2 \%$ & $62.6 \%$ \\
PN1993-1999 & HIV/AIDS & 124 & $4.2 \%$ & $66.8 \%$ \\
R & Film studies & 93 & $3.2 \%$ & $70.0 \%$ \\
HQ1101-2030.7 & Medicine & 66 & $2.3 \%$ & $72.3 \%$ \\
C,D,E,F,HN & Women's studies & 64 & $2.2 \%$ & $74.5 \%$ \\
GN & History & 60 & $2.1 \%$ & $76.6 \%$ \\
BF & Anthropology & 59 & $2.0 \%$ & $78.6 \%$ \\
P87-96 & Psychology & 52 & $1.8 \%$ & $80.4 \%$ \\
HQ1088-1090.7 & Communication studies & 51 & $1.7 \%$ & $82.1 \%$ \\
G & Men's studies & 44 & $1.5 \%$ & $83.6 \%$ \\
& Geography & &
\end{tabular}




\begin{tabular}{llccc} 
L & Education & 43 & $1.5 \%$ & $85.1 \%$ \\
RC435-571 & Psychiatry & 40 & $1.4 \%$ & $86.5 \%$ \\
H & Social sciences (General) & 36 & $1.2 \%$ & $87.7 \%$ \\
BJ,BL,BR,BS,BT,BV,BX & Religion, Theology & 32 & $1.1 \%$ & $88.8 \%$ \\
HT & Urban studies & 23 & $0.8 \%$ & $89.6 \%$ \\
RC475-489 & Art therapy & 21 & $0.7 \%$ & $90.3 \%$ \\
& Other & 305 & $10.4 \%$ & $100.7 \%$ \\
& Unclassified & 324 & - & - \\
\hline
\end{tabular}

Overall, there were 633 citations classified in LGBTQ studies, which constitute 19.5 percent of all citations, a percentage far lower than previous studies. However, 324 citations were unclassified, and these were removed from the total. These were eliminated because they did not represent a discipline or area of study, and they were not assigned a topic of LGBTQ studies. Those citations classified in A (General Works) were retained because many citations about LGBTQ topics appeared in general interest periodicals or newspapers.

There were 630 citations that were assigned a topic of LGBTQ studies based on the titles of the works cited. Table 3 lists the document types with the corresponding number of citations that were assigned a topic of LGBTQ studies but were not classified in LGBTQ studies. The 630 references were added to the 633 citations classified in LGBTQ studies, which produced a percentage of 43.3 percent. This indicates that LGBTQ studies, compared to previous research, has only an average level of interdisciplinarity. It must be recalled that the median of previous studies ranges from 37.6 percent to 40.9 percent. Thus, the 43.3 percent is slightly above average. It also indicates that LGBTQ studies has a distinct disciplinary focus, taking into account that the social sciences showed median percentages of citations to their own fields that ranged from 43.4 percent to 49.1 percent, according to Levitt, Thelwell, and Oppenheim. 
Table 3.

Formats of LGBTQ content not classified in HQ74HQ77.95

\begin{tabular}{lr}
\hline Format & Number \\
\hline Journal articles & 261 \\
Monographs & 163 \\
Chapters in edited books & 110 \\
Newspaper articles & 41 \\
Articles in popular periodicals & 32 \\
Conference papers & 20 \\
Government document & 2 \\
Dissertation & 1 \\
Total & $\mathbf{6 3 0}$
\end{tabular}

The 43.3 percent applied to all document types. Formats were examined to see if there weare differences in the level of interdisciplinarity and to ascertain whether there was a disciplinary focus with each format. Table 4 shows the breakdown by predominant document types. There were 1,201 citations to monographs and a further 463 references to chapters in books, totaling 51.3 percent of all citations. There were 353 cited journals with a total of 709 citations, averaging a little more than two citations per journal.

Table 4.

Citations by format

\begin{tabular}{lrc}
\hline Format & Number of citations & Percentage of total citations \\
\hline Monograph & 1,201 & $37.03 \%$ \\
Journal article & 709 & $21.86 \%$ \\
Chapter/essay in books & 463 & $14.27 \%$ \\
Periodical article & 384 & $11.87 \%$ \\
Newspaper article & 130 & $4.01 \%$ \\
Website & 122 & $3.76 \%$ \\
Conference & 88 & $2.71 \%$ \\
Other & 146 & $4.50 \%$ \\
Total & $\mathbf{3 , 2 4 3}$ & $\mathbf{1 0 0 . 0 1 \%}$
\end{tabular}


There are two ways to count citations to journal articles. The first is to tally the total number of citations for each journal. Table 5 lists the top 20 journals by number of total citations, along with the percentages of total citations, the cumulative percentages of references, and their status in LGBT Life. The top 18.4 percent of journals accounted for 53.27 percent of citations. There is more subject scatter or dispersal across a larger number of resources, which would normally indicate higher interdisciplinarity. However, 261 articles in journals of other disciplines were about LGBTQ topics, accounting for 36.8 percent of total journal article citations. This eliminates the impact of subject scatter or dispersal. 


\section{Table 5.}

Most frequently cited journal titles

\begin{tabular}{|c|c|c|c|c|c|}
\hline Rank & Journal title & $\begin{array}{l}\text { Number } \\
\text { of } \\
\text { citations }\end{array}$ & $\begin{array}{c}\text { Percentage } \\
\text { of total } \\
\text { journal } \\
\text { citations }\end{array}$ & $\begin{array}{l}\text { Cumulative } \\
\text { percentage of } \\
\text { total journal } \\
\text { citations }\end{array}$ & $\begin{array}{l}\text { Status in } \\
\text { LGBT Life }\end{array}$ \\
\hline 1 & Journal of Homosexuality & 37 & $5.22 \%$ & $5.22 \%$ & Core* \\
\hline 2 & $\begin{array}{l}\text { GLQ: A Journal of Lesbian } \\
\text { and Gay Studies }\end{array}$ & 20 & $2.82 \%$ & $8.04 \%$ & Core \\
\hline 3 & Archives of Sexual Behavior & 15 & $2.12 \%$ & $10.16 \%$ & Core \\
\hline 3 & Journal of Sex Research & 15 & $2.12 \%$ & $12.28 \%$ & Core \\
\hline 5 & Gender, Place \& Culture & 13 & $1.83 \%$ & $14.11 \%$ & Not indexed \\
\hline 5 & Social Text & 13 & $1.83 \%$ & $15.94 \%$ & Not indexed \\
\hline 7 & October & 11 & $1.55 \%$ & $17.49 \%$ & Not indexed \\
\hline 8 & Social Problems & 10 & $1.41 \%$ & $18.90 \%$ & Not indexed \\
\hline 9 & Socialist Review & 8 & $0.99 \%$ & $19.89 \%$ & Not indexed \\
\hline 10 & Afterimage & 7 & $0.99 \%$ & $20.88 \%$ & Not indexed \\
\hline 10 & $\begin{array}{l}\text { American Journal of Public } \\
\text { Health }\end{array}$ & 7 & $0.99 \%$ & $21.87 \%$ & Priority $†$ \\
\hline 10 & Art Journal & 7 & $0.99 \%$ & $22.86 \%$ & Not indexed \\
\hline 10 & Children's Geographies & 7 & $0.99 \%$ & $23.85 \%$ & Not indexed \\
\hline 10 & Journal of LGBT Youth & 7 & $0.99 \%$ & $24.84 \%$ & Core \\
\hline 15 & Art Therapy & 6 & $0.85 \%$ & $25.69 \%$ & Not indexed \\
\hline 15 & $\begin{array}{l}\text { Critical Quarterly } \\
\text { International Journal of }\end{array}$ & 6 & $0.85 \%$ & $26.54 \%$ & Not indexed \\
\hline 15 & $\begin{array}{l}\text { Urban and Regional } \\
\text { Research }\end{array}$ & 6 & $0.85 \%$ & $27.39 \%$ & Not indexed \\
\hline 15 & Political Theory & 6 & $0.85 \%$ & $28.24 \%$ & Not indexed \\
\hline 15 & Salmagundi & 6 & $0.85 \%$ & $29.09 \%$ & Not indexed \\
\hline 15 & Urban Life & 6 & $0.85 \%$ & $29.94 \%$ & Not indexed \\
\hline
\end{tabular}

The second way to count citations to journal articles is to calculate the number of theses that cite a journal. This method guards against a single thesis citing one journal many times. Table 6 lists the journals with citations from three or more theses. The top two journals in both Table 5 and Table 6 are the Journal of Homosexuality and GLQ: A Journal of Lesbian and Gay Studies, the two leading scholarly journals in LGBTQ studies. The Journal of Sex Research and Archives of Sexual Behavior, both classified in sexuality studies, are also highly cited. The fifth highly cited journal is Gender, Place and \& Culture (classified in geography), and the sixth is 
Social Text (classified in social history), each with 13 citations. However, 10 of the 13 citations to Gender, Place and \& Culture and 7 of the 13 citations to Social Text deal with LGBTQ topics. There were 68 citations to LGBTQ journals, which were added to the 261 journal article citations with LGBTQ topics, producing a total of 329 citations, representing 46.4 percent of all journal article citations, which confirms a distinct disciplinary focus on LGBTQ studies.

Table 6.

Most frequently cited journals by number of theses

\section{Rank Journal title}

1 Journal of Homosexuality

2 GLQ: A Journal of Lesbian and Gay Studies

3 October

$4 \quad$ Social Problems

$4 \quad$ Social Text

$6 \quad$ Atlantis

6 differences: A Journal of Feminist Cultural Studies

6 Journal of Sex Research

9 Art Journal

$9 \quad$ Critical Inquiry

9 Critical Quarterly

9 Discourse

$9 \quad$ Salmagundi

$9 \quad$ Sex Roles

9 Social \& Cultural Geography

$9 \quad$ Socialist Review

\section{Total} number of theses

$\begin{array}{ll}8 & 33.33 \% \\ 7 & 29.17 \% \\ 6 & 25.00 \% \\ 5 & 20.83 \% \\ 5 & 20.83 \% \\ 4 & 16.66 \% \\ 4 & 16.66 \% \\ 4 & 16.66 \% \\ 3 & 12.50 \% \\ 3 & 12.50 \% \\ 3 & 12.50 \% \\ 3 & 12.50 \% \\ 3 & 12.50 \% \\ 3 & 12.50 \% \\ 3 & 12.50 \% \\ 3 & 12.50 \%\end{array}$

The disciplinary focus is also evident in popular periodicals. At 11.87 percent, popular periodicals seem to have a small but significant portion of total citations. There were 384 citations to 103 popular periodicals, the top 15 of which are listed in Table 7. Seven of the top 15 are LGBTQ community periodicals. A total of 24 magazines were classified in LGBTQ studies with 205 citations and a further 32 references about LGBTQ topics in mainstream magazines, representing 61.7 percent of all periodical citations. LGBTQ studies, at least in terms of popular periodicals, has a strong disciplinary focus. 
Table 7.

Most frequently cited periodicals

\begin{tabular}{rlc}
\hline Rank & Periodical title & $\begin{array}{c}\text { Number } \\
\text { of } \\
\text { citations }\end{array}$ \\
\hline 1 & Daily Xtra (Toronto) & 70 \\
2 & Gay Community News & 37 \\
3 & Time & 29 \\
4 & Advocate & 27 \\
5 & Body Politic & 25 \\
6 & Newsweek & 15 \\
7 & Out & 10 \\
8 & Sports Illustrated & 10 \\
9 & FUSE & 9 \\
10 & Scientific American & 8 \\
11 & Fugues & 6 \\
12 & Artforum & 5 \\
12 & New York Native & 5 \\
14 & Cineaste & 4 \\
14 & Parachute & 4 \\
\hline
\end{tabular}

Books were the most prevalent document type, representing 51.3 percent of all citations. Table 8 shows the 35 most cited monographs and edited books. The books are ranked by number of citing theses, with a minimum of three citations. Although 20 of the 28 theses were written from 1999 onward, only two books on the list were published after 1998. Some of these are seminal works, such as Kinsey, Pomeroy, and Martin's 1948 book, Sexual Behavior in the Human Male, and Foucault's 1978 book, The History of Sexuality. Two authors each have 2 books in the top 13. These are Epistemology of the Closet and Tendencies by Sedgwick and Gender Trouble: Feminism and the Subversion of Identity and Bodies That Matter: On the Discursive Limits of "Sex" by Butler. Two books-Hard to Imagine: Gay Male Eroticism in Photography and Film from Their Beginnings to Stonewall and Invisible Lives: The Erasure of Transsexual and Transgendered People — are by Thomas Waugh and Viviane Namaste, respectively, two Concordia faculty members. Sortir de l'ombre: Histoires des communautés lesbienne et gaie de Montréal [Out of the shadows: Stories from Montreal's lesbian and gay 
communities], a book of local interest edited by Irène Demczuk and Frank Remiggi, is one of the 65 resources written in French, the only other language represented in this study.

Table 8.

Most cited monographs and edited books

\begin{tabular}{|c|c|c|c|c|c|}
\hline $\begin{array}{l}\text { Library of } \\
\text { Congress } \\
\text { Classification } \\
\text { call number }\end{array}$ & Discipline & Topic & Title & Year & $\begin{array}{c}\text { Number } \\
\text { of } \\
\text { theses }\end{array}$ \\
\hline HQ12 & Sexuality & & History of Sexuality & 1978 & 13 \\
\hline HQ1075 & Sexuality & & $\begin{array}{c}\text { Gender Trouble: Feminism and } \\
\text { the Subversion of Identity }\end{array}$ & 1990 & 9 \\
\hline PS374 & Literature & LGBTQ & Epistemology of the Closet & 1990 & 8 \\
\hline HQ76.25 & LGBTQ & & $\begin{array}{l}\text { Inside/Out: Lesbian Theories, } \\
\text { Gay Theories }\end{array}$ & 1991 & 8 \\
\hline HQ76.25 & LGBTQ & & $\begin{array}{l}\text { Lesbian and Gay Studies } \\
\quad \text { Reader }\end{array}$ & 1993 & 8 \\
\hline PN1995.9 & Film Studies & LGBTQ & $\begin{array}{l}\text { How Do I Look? Queer Film } \\
\text { and Video }\end{array}$ & 1991 & 7 \\
\hline HQ1190 & $\begin{array}{l}\text { Women's } \\
\text { Studies }\end{array}$ & & $\begin{array}{l}\text { Bodies That Matter: On the } \\
\text { Discursive Limits of "Sex" }\end{array}$ & 1993 & 6 \\
\hline HQ76.3 & LGBTQ & & $\begin{array}{c}\text { Fear of a Queer Planet: Queer } \\
\text { Politics and Social Theory }\end{array}$ & 1993 & 6 \\
\hline RA644 & AIDS & & $\begin{array}{l}\text { AIDS: Cultural } \\
\quad \text { Analysis/Cultural Activism }\end{array}$ & 1988 & 5 \\
\hline HV8666 & Sociology & & $\begin{array}{l}\text { Discipline and Punish: The } \\
\text { Birth of the Prison }\end{array}$ & 1977 & 5 \\
\hline HQ75.5 & LGBTQ & & Female Masculinity & 1998 & 5 \\
\hline HQ76.8 & LGBTQ & & $\begin{array}{c}\text { Never Going Back: A History of } \\
\text { Queer Activism in Canada }\end{array}$ & 2002 & 5 \\
\hline RC607 & AIDS & & $\begin{array}{l}\text { Policing Desire: Pornography, } \\
\text { AIDS and the Media }\end{array}$ & 1998 & 5 \\
\hline PN56 & Literature & LGBTQ & Tendencies & 1993 & 5 \\
\hline RA644 & AIDS & & $\begin{array}{l}\text { And the Band Played On: } \\
\text { Politics, People, and the } \\
\text { AIDS Epidemic }\end{array}$ & 1987 & 4 \\
\hline NX180 & Visual Arts & & $\begin{array}{l}\text { Fluid Exchanges: Artists and } \\
\text { Critics in the AIDS Crisis }\end{array}$ & 1992 & 4 \\
\hline HQ77.9 & LGBTQ & & $\begin{array}{l}\text { Gender Outlaw: On Men, } \\
\quad \text { Women, and the Rest of Us }\end{array}$ & 1994 & 4 \\
\hline
\end{tabular}




\begin{tabular}{|c|c|c|c|c|}
\hline HQ76.25 & LGBTQ & $\begin{array}{l}\text { Mapping Desire: Geographies } \\
\text { of Sexualities }\end{array}$ & 1995 & 4 \\
\hline HQ18 & Sexuality & $\begin{array}{l}\text { Regulation of Desire: Sexuality } \\
\text { in Canada }\end{array}$ & 1987 & 4 \\
\hline RA644 & AIDS & $\begin{array}{l}\text { Sex and Germs: The Politics of } \\
\text { AIDS }\end{array}$ & 1986 & 4 \\
\hline HQ71 & Sexuality & $\begin{array}{l}\text { Body Guards: The Cultural } \\
\text { Politics of Gender } \\
\text { Ambiguity }\end{array}$ & 1991 & 3 \\
\hline HQ76.2 & LGBTQ & $\begin{array}{l}\text { Gay New York: Gender, Urban } \\
\text { Culture, and the Makings of } \\
\text { the Gay Male World, 1890- } \\
1940\end{array}$ & 1994 & 3 \\
\hline TR681 & Photography LGBTQ & $\begin{array}{l}\text { Hard to Imagine: Gay Male } \\
\text { Eroticism in Photography } \\
\text { and Film from Their } \\
\text { Beginnings to Stonewall }\end{array}$ & 1996 & 3 \\
\hline RA644 & AIDS & Inventing AIDS & 1990 & 3 \\
\hline HQ77.95 & LGBTQ & $\begin{array}{l}\text { Invisible Lives: The Erasure of } \\
\text { Transsexual and } \\
\text { Transgendered People }\end{array}$ & 2000 & 3 \\
\hline HQ1088 & $\begin{array}{l}\text { Men's } \\
\text { Studies }\end{array}$ & $\begin{array}{l}\text { Making of Masculinities: The } \\
\text { Men's Studies }\end{array}$ & 1987 & 3 \\
\hline HQ76.3 & LGBTQ & $\begin{array}{l}\text { Male Homosexuals: Their } \\
\text { Problems and Adaptations }\end{array}$ & 1974 & 3 \\
\hline PN51 & Literature & Marxism and Literature & 1977 & 3 \\
\hline HQ1090 & $\begin{array}{l}\text { Men’s } \\
\text { Studies }\end{array}$ & $\begin{array}{l}\text { Beyond Patriarchy: Essays by } \\
\text { Men on Pleasure, Power } \\
\text { and Change }\end{array}$ & 1987 & 3 \\
\hline HN291 & Sociology & $\begin{array}{l}\text { Presentation of Self in Everyday } \\
\quad \text { Life }\end{array}$ & 1959 & 3 \\
\hline HQ76.25 & LGBTQ & Queer Theory: An Introduction & 1996 & 3 \\
\hline HX286 & $\begin{array}{l}\text { Political } \\
\text { Science }\end{array}$ & $\begin{array}{l}\text { Selections from the Prison } \\
\text { Notebooks of Antonio } \\
\text { Gramsci }\end{array}$ & 1971 & 3 \\
\hline HQ18 & Sexuality & $\begin{array}{l}\text { Sexual Behavior in the Human } \\
\text { Male }\end{array}$ & 1948 & 3 \\
\hline HQ71 & Sexuality & Sexual Deviance & 1967 & 3 \\
\hline HQ76.8 & LGBTQ & $\begin{array}{l}\text { Sortir de l'ombre: Histoires des } \\
\text { communautés lesbienne et } \\
\text { gaie de Montréal }\end{array}$ & 1998 & 3 \\
\hline
\end{tabular}

Among the top three books are History of Sexuality, Gender Trouble, and Epistemology of the Closet. Another three LGBTQ books complete the top six. It is not surprising to see six 
books about AIDS on the list, given that 4 of the 28 theses were about AIDS. The age of the AIDS books, with none more recent than 1998, is explained by the fact that the four theses were written prior to 1999 . In addition to the AIDS books, 21 of the 35 books are about LGBTQ or sexuality topics. There were 260 monographs and 99 chapters in edited books that were classified in LGBTQ studies, and a further 273 monographs and edited books that were assigned a topic of LGBTQ studies, representing 43.5 percent of monographs and edited books in LGBTQ studies, confirming a distinct emphasis on this field of study.

Most citation analyses do not include lists of cited authors, but authors and their areas of expertise are important to a discipline. Table 9 lists the most cited authors by the number of theses that cite them, along with the total number of citations. The discipline or area of expertise, based on the LCC classification and the subject headings of their books, is also included. Listing authors by number of theses indicates which authors have a wider attraction than the total number of citations, thereby minimizing the disproportionate usage that can happen when one thesis cites one specific author many times. Such is the case with two authors who were cited 14 times and 11 times by one thesis. The top three authors are Michel Foucault, Eve Kosofsky Sedgwick, and Judith Butler. These three authors are central to LGBTQ and sexuality studies, at least at Concordia. Fifteen of the 18 authors have written about LGBTQ topics, and the other three authors have written about AIDS, revealing a core list of authors that shows a disciplinary focus on LGBTQ studies.

Table 9.

Most cited authors

\begin{tabular}{llll}
\hline Author & Discipline(s) & $\begin{array}{l}\text { Number } \\
\text { of theses }\end{array}$ & $\begin{array}{l}\text { Number of } \\
\text { citations }\end{array}$ \\
\hline Foucault, Michel & Sexuality/LGBTQ & 13 & 29 \\
Sedgwick, Eve Kosofsky & Literature/LGBTQ & 10 & 15 \\
Butler, Judith & Sexuality/LGBTQ & 9 & 14 \\
Warner, Michael & LGBTQ & 7 & 9 \\
Halberstam, Judith & Sexuality/LGBTQ & 6 & 7 \\
Sontag, Susan & Literature/AIDS & 6 & 6 \\
Crimp, Douglas & Visual arts/AIDS & 5 & 9 \\
Watney, Simon & Visual arts/AIDS & 5 & 7 \\
Califia, Pat & Literature/LGBTQ & 4 & 9
\end{tabular}




$\begin{array}{llll}\text { Patton, Cindy } & \text { AIDS/LGBTQ } & 4 & 8 \\ \text { Weeks, Jeffrey } & \text { History/LGBTQ } & 4 & 7 \\ \text { Altman, Dennis } & \text { LGBTQ } & 4 & 6 \\ \text { Waugh, Thomas } & \text { Film studies/LGBTQ } & 4 & 6 \\ \text { Dyer, Richard } & \text { Film studies/LGBTQ } & 4 & 5 \\ \text { Mohr, Richard } & \text { Philosophy/LGBTQ } & 4 & 5 \\ \text { Jagose, Annamarie } & \text { LGBTQ } & 4 & 4 \\ \text { Kinsman, Gary } & \text { LGBTQ } & 4 & 4 \\ \text { Shilts, Randy } & \text { AIDS/LGBTQ } & 4 & 4\end{array}$

\section{Discussion}

Newer fields of study are often viewed as interdisciplinary. LGBTQ studies, with its recent emergence as a field of study in the 1990s, is largely assumed to be highly interdisciplinary. In addition, being so new, LGBTQ studies lacks a large body of long-standing literature to cite. With the assumption of interdisciplinarity, LGBTQ studies would be expected to cite within its own field at around a 20 percent rate, the lower end that previous research reported. At first glance, the field did indeed exhibit high interdisciplinarity, with 19.5 percent of total citations or 21.7 percent of classified citations $(n=2,919)$ to its own field. However, a closer examination of citations reveals that LGBTQ studies has only an average level of interdisciplinarity. The 630 references on LGBTQ topics in the literatures of other fields, in addition to the 633 classified in LGBTQ studies, produce a percentage of 43.3 percent of citations to LGBTQ studies, not indicative of a highly interdisciplinary field.

When a field does lacks a long-standing body of scholarly literature, such as LGBTQ studies, it may rely on older, related fields of study, such as sexuality studies. For example, important works in LGBTQ studies are classified in sexuality studies. Kinsey, Pomeroy, and Martin's Sexual Behavior in the Human Male (1948), Foucault's History of Sexuality (1978), and Butler's Gender Trouble (1990) are all classified in sexuality studies and are highly cited books in this study. Other highly cited books classified in sexuality studies include Regulation of Desire: Sexuality in Canada (1987) by Gary Kinsman; Body Guards: The Cultural Politics of Gender Ambiguity (1991), edited by Julia Epstein and Kristina Staub; and Sexual Deviance (1967), edited by D. Richard Laws and William O'Donohue. All of these books deal with LGBTQ topics. 
Although LGBTQ studies may lack a long-standing body of literature, it nevertheless has a recent body of LGBTQ or sexuality literature on which to draw. The average age of all the citations is 10.2 years, and the median age is 7 , without counting the 158 undated references. Forty-six citations were published in the same year as the date of submission of the thesis. The oldest item cited was a 1758 book entitled L'Onanisme [Onanism], a book about male masturbation by Samuel Auguste David Tissot, who was a Swiss physician, that is classified in medicine. There were 1,927 citations less than 10 years old, for a percentage of 62.5 percent. The average age of books (monographs and chapters in edited books) is 12.4 years, and the median is 9. The average age for journal articles is 9.4 years, and the median is 7 . This confirms that cited books are generally older than cited journal articles. In Antell's study, the average citation age of books was 16.1 years and the median was 10, while the average citation age of journal articles was 11.1 years and the median was 7 . Antell also reported that the overall average age was 13.5 years and the median age was 8 , while 56.2 percent of the citations were less than 10 years old. ${ }^{30}$ These results are sufficiently similar to warrant a conclusion that recency is important in both the scholarly literature and master's theses in LGBTQ studies.. Citing recent scholarship and the average interdisciplinarity indicates that LGBTQ studies has its own new body of literature.

Few disciplines cite within their own fields at a rate of more than 50 percent. LGBTQ studies, in several areas, consistently exhibits an average level of interdisciplinarity, with percentages in the 40s or higher. Overall, 43.3 percent of citations are within LGBTQ studies, with journal article citations at 46.4 percent, popular periodicals at 61.7 percent, and monographs and edited books at 43.5 percent. There are challenges regarding academic library support for LGBTQ studies, with some of its own literature published in the literatures of other fields. The 630 citations on LGBTQ topics are actually about two disciplines: the discipline in which it is classified and LGBTQ studies, making them co-disciplinary.

Collection development can be particularly challenging. A single LGBTQ selector would need to browse the literatures of many other disciplines to identify LGBTQ content. Knowing the top disciplines from which LGBTQ studies borrows - medicine, literature, sociology, visual arts, and film studies - narrows the number of disciplines that require browsing. Nevertheless, perusing the literatures of these five disciplines and others could take a great deal of time. A better solution is to adopt a collaborative approach to collection development, wherein selectors, particularly those in the top five disciplines, share LGBTQ material. 
With its average interdisciplinarity and recent body of literature, LGBTQ studies resembles a traditional discipline in the sense that it has its own reference apparatus, such as dictionaries, encyclopedias, and the LGBT Life database. For many basic reference questions, which require only a handful of sources, LGBT Life is sufficient. LGBT Life with Full Text indexes LGBTQ journals, of which there are few, and sexuality journals, as well as providing access to 160 full-text books. However, for more complex reference questions, and for those questions not answered by LGBT Life, it is important to expand the selection of databases. Reference librarians and subject specialists need to be aware that there is substantial publication of LGBTQ topics in the literatures of other disciplines. This awareness can improve reference work, research assistance, and library instruction by going beyond LGBT Life. Once again, knowing the top five disciplines narrows the field. Searching the databases of other literatures or multidisciplinary databases is important, given that 630 citations in this study are co-disciplinary.

Providing reference services and research assistance necessitates the usage of several sources. The database LGBT Life, with its limited journal coverage outside of LGBTQ and sexuality studies, is insufficient. As shown in Table 5, 14 of the top 20 journals are not indexed by LGBT Life. Core journals are those that are indexed cover-to-cover, while the index for priority journals includes only the articles that are relevant to the field. Including more priority journals could improve the database. The 65 most cited journals in this study contain 52 journals that are not indexed in LGBT Life, necessitating library workshops to include multidisciplinary databases, such as Academic Search Complete or the Gender Studies Database, or the databases that serve medicine, literature, sociology, visual arts, and film studies. Knowing the core journals, main books, and major authors in LGBTQ studies increases the subject librarian's ability to communicate with students and to recommend specific books and authors in LGBTQ and sexuality studies, particularly for graduate students beginning their research on these topics. In addition, the 261 journal articles that are co-disciplinary indicate that subject librarians need to maintain subscriptions to journals outside of the core journals indexed by LGBT Life, as Antell has stated. ${ }^{31}$

Although the literature of LGBTQ studies is recent, a few important older sources, particularly books, are central to LGBTQ studies. Only two books are listed in both Antell's 39 highly cited books and the 35 books in the literature of master's students. Only two books on each list were published after 1999, with most books on the lists appearing in the 1980s and 
1990s. The two books on both lists are the 1948 work Sexual Behavior in the Human Male by Kinsey and his coauthors and Foucault's 1978 book History of Sexuality, making both books essential reading in LGBTQ studies. An explanation for the dissimilarities in the book lists may be that graduate students emphasize familiarization with the literature emanating from the teaching they receive, whereas faculty researchers may have a greater latitude in the books they choose to cite for their research. Knowing that LGBTQ studies has a disciplinary focus in terms of books, journal articles, and popular periodicals and that its literature is mainly recent would help reference librarians and subject specialists to narrow the focus of searches for reference and research transactions, particularly for journal articles.

Few academic journals are dedicated to LGBTQ studies, limiting the number of papers that can be submitted to such journals. The four most cited journals in this study are the Journal of Homosexuality, GLQ, the Archives of Sexual Behavior, and the Journal of Sex Research, with the latter two classified in sexuality studies. These are core journals in LGBT Life. There is thus a small core list of journals pertaining to LGBTQ studies and many journals that publish a few LGBTQ articles each, requiring reference and subject librarians to go beyond databases such as LGBT Life. There were 261 LGBTQ articles published in journals of other disciplines, while only 68 articles appeared in LGBTQ journals. This indicates that publication in LGBTQ studies is strong and that journals of other fields of study have accepted LGBTQ topics within their disciplines. In this sense, LGBTQ topics in journals of other disciplines represent a form of normalization.

\section{Limitations}

This is a preliminary study with several limitations. Firstly, this study used master's theses for citation analysis. Secondly, it was limited to one university. It is necessary to expand studies of interdisciplinarity in LGBTQ studies to either confirm or refute the finding that LGBTQ studies has an average level of interdisciplinarity, rather than a high level, and that it has a disciplinary focus with its own body of literature.

\section{Conclusion}

The interdisciplinarity of LGBTQ studies was tested empirically through a citation analysis that included Library of Congress Classification call numbers and a count of titles with LGBTQ topics. At first glance, LGBTQ studies appeared to have a high level of interdisciplinarity, with 633 citations classified in HQ74-HQ77.95, which represented 19.5 percent of all references. 
Adding the citations with LGBTQ topics classified in other disciplines produced a percentage of 43.3 percent. Previous studies showed that all disciplines or fields of study are interdisciplinary, but the level of interdisciplinarity varies, with percentages in the 40s about average. This average interdisciplinarity was consistent across document types or formats. Journal article citations with LGBTQ content stood at 46.4 percent, popular periodicals at 61.7 percent, and monographs and edited books at 43.5 percent, all of which supportings the conclusion that LGBTQ studies has an average, rather than a high, level of interdisciplinarity, though a high level is sometimes assumed for newer fields of study.

The average percentages of citations that show a disciplinary emphasis on LGBTQ studies indicate that LGBTQ studies has its own body of literature. This body of literature is a combination of references classified in LGBTQ studies, as per the Library of Congress Classification system, and citations classified in other literatures that have an LGBTQ topic. Some of the LGBTQ literature predates the emergence of LGBTQ studies in the early 1990s. These are seminal works, with some classified in sexuality studies. The average and median ages of the citations in master's theses, along with the average interdisciplinarity, support the idea that the literature of LGBTQ studies is recent. LGBTQ studies is largely based on its own literature, rather than the literatures of other disciplines.

The average interdisciplinarity informs reference work, research assistance, and bibliographic instruction. This study confirms that students, particularly master's students, are looking for LGBTQ content wherever it is published. The database LGBT Life, with its limited journal coverage outside of LGBTQ and sexuality studies, is insufficient. It indexes only 13 of the top 65 journals. The 261 citations to journal articles outside of LGBTQ studies shows that a substantial amount of LGBTQ publication occurs in other disciplines. This information can help reference librarians and subject specialists to improve their services by going beyond LGBT Life in reference and research transactions, as well as library workshops.

The average interdisciplinarity is evident in the lists of cited books and authors that reveal a core literature of LGBTQ studies for master's students. The three core authors for master's students are Foucault, who is also important in the cited scholarly literature, Sedgwick, and Butler. Their works are also the most highly cited books, namely the History of Sexuality, Epistemology of the Closet, and Gender Trouble. Although the list of cited journals shows a large dispersal or scatter across many resources, three or four journals in LGBTQ and sexuality 
studies emerge as core journals in both the scholarly literature and master's theses. These are the Journal of Homosexuality, Archives of Sexual Behavior, the Journal of Sex Research, and GLQ. It is important for subject librarians in LGBTQ studies to familiarize themselves with this core literature when providing research assistance to students, increasing the subject librarian's ability to communicate with students and to recommend specific books and authors. This level of communication is essential to providing reference service, research assistance, and bibliographic instruction, giving the subject librarian a knowledge of the core literature and rendering transactions with students more effective, and perhaps more enjoyable.

\section{Notes}

1. Jack Collins, "Matters of Fact: Establishing a Gay and Lesbian Studies Department," Journal of Homosexuality 24, 1-2 (1993): 109-11; City College of San Francisco, "LGBTQQI [lesbian, gay, bisexual, transgender, queer, questioning, and intersex] Studies," accessed June 7, 2015, http://www.ccsf.edu/en/educational-programs/school-and-departments/school-ofbehavioral-and-social-sciences/LGBT.html.

2. Henry L. Minton, "The Emergence of Gay and Lesbian Studies," Journal of Homosexuality 24, 1-2 (1993): 1; Barbara Campbell, "200 Start Fight on Homosexual 'Myths," New York Times, November 23, 1973, 24; City University of New York, "LGBTQ Studies," accessed June 15, 2015, http://www.cuny.edu/academics/programs/lgbtq.html.

3. "Gay Studies at University of Toronto,” Body Politic 20 (October 1975): 9.

4. Dolores Klaich, “The Price of Going Mainstream,” Gay \& Lesbian Review Worldwide 22, 3 (May-June 2015): 17.

5. Ibid.; John G. Younger, "University LGBT/Queer Programs: Lesbian, Gay, Bisexual,

Transgender, Transsexual \& Queer Studies in the USA and Canada,” accessed June 20, 2015, http://www.people.ku.edu/ jyounger/lgbtqprogs.html.

6. Minton, "The Emergence of Gay and Lesbian Studies," 1-6.

7. Karen Antell, “The Citation Landscape of Scholarly Literature in LGBT Studies: A Snapshot for Subject Librarians,” College \& Research Libraries 73, 6 (November 2012): 584-85.

8. Concordia University, “A Look at the Levies," The Link, March 26, 2013, accessed June 5, 2015, http://thelinknewspaper.ca/article/4213. 
9. Concordia University, "About the Program," accessed June 5, 2015, http://www.concordia.ca/finearts/cinema/programs/undergraduate/sexuality-minor/aboutsexuality-minor.html.

10. OED [Oxford English Dictionary] Online, under the heading "interdisciplinary"; under the heading "multidisciplinary," accessed June 22, 2015, http://www.oed.com.

11. Jean-Pierre V. M. Hérubel, "Musings on Disciplinary Morphology and Nomenclature in the Humanities and Social Sciences: Implications for Book Selection,” Journal of Scholarly Publishing 39, 1 (2007): 57.

12. Michael F. Winter, "Specialization and Interdisciplinary Growth in the Social Sciences," Behavioral \& Social Sciences Librarian 10, 2 (1991): 1-7.

13. Jonathan M. Levitt, Mike Thelwall, and Charles Oppenheim, "Variations between Subjects in the Extent to Which the Social Sciences Have Become More Interdisciplinary," Journal of the American Society for Information Science and Technology 62, 6 (2011): 1120-22.

14. Graham Sheriff, "Information Use in History: A Citation Analysis of Master's Level Theses," portal: Libraries and the Academy 10, 2 (2010): 174, 179.

15. Virginia Kay Williams and Christine Lea Fletcher, "Materials Used by Master's Students in Engineering and Implications for Collection Development: A Citation Analysis," Issues in Science and Technology Librarianship 45 (Winter 2006).

16. Bluma C. Peritz and Dina Sor, "The Use of Libraries by Graduate Students in Psychology as Indicated by Citations," Collection Management 12, 3-4 (1990): 18.

17. Juris Dilevko and Keren Dali, "Improving Collection Development and Reference Services for Interdisciplinary Fields through Analysis of Citation Patterns: An Example Using Tourism Studies," College \& Research Libraries 65, 3 (2004): 224-25.

18. Li Zhang, "Discovering Information Use in Agricultural Economics: A Citation Study," Journal of Academic Librarianship 33, 3 (2007): 409, 403.

19. Robert N. Broadus, "The Literature of the Social Sciences: A Survey of Citation Studies," International Social Science Journal 23, 2 (1971): 238.

20. Joy Thomas, "Never Enough: Graduate Student Use of Journals - Citation Analysis of Social Work Theses,” Behavioral \& Social Sciences Librarian 19, 1 (2000): 9. 
21. Elaine M. Lasda Bergman, "Social Gerontology-Integrative and Territorial Aspects: A Citation Analysis of Subject Scatter and Database Coverage," Behavioral \& Social Sciences Librarian 30, 3 (2011): 166, 169.

22. William C. Robinson and Paul E. Posten, "Literature Use of Scholars Publishing in Leading Anthropology Periodicals," Behavioral \& Social Sciences Librarian 23, 2 (2005): 13.

23. Thomas Weissinger, "The Core Journal Concept in Black Studies," Journal of Academic Librarianship 36, 2 (2010): 121.

24. Li Zhang, "Citation Analysis for Collection Development: A Study of International Relations Journal Literature," Library Collections, Acquisitions, \&Technical Services 31, 3-4 (2007): 201-2.

25. Joy Thomas, “Graduate Student Use of Journals: A Bibliometric Study of Psychology Theses," Behavioral \& Social Sciences Librarian 12, 1 (1993): 6.

26. Molly Strothmann, "Use of Non-Social Work Journals in Social Work Research: Results of a Citation Analysis," Behavioral \& Social Sciences Librarian 29, 4 (2010): 252.

27. Karen Antell, “The Citation Landscape of Scholarly Literature in LGBT Studies," College \& Research Libraries 73, 6 (2012): 586-93.

28. Ben Christensen, "Minoritization vs. Universalization: Lesbianism and Male Homosexuality in LCSH [Library of Congress Subject Headings] and LCC [Library of Congress Classification]," Knowledge Organization 35, 4 (2008): 233-35.

29. Emily Drabinski, "Queering the Catalog: Queer Theory and the Politics of Correction," Library Quarterly 83, 2 (2013): 95-98.

30. Antell, "The Citation Landscape of Scholarly Literature in LGBT Studies," 595.

31. Ibid., 594. 